\title{
7. Språk i hjemmet og naturfagprestasjoner fra TIMSS 2015 til TIMSS 2019
}

\section{Anne-Catherine W.G. Lehre og Trude Nilsen}

Sammendrag Språk er en viktig faktor i et likeverdsperspektiv. Denne studien bruker data fra TIMSS 2015 og TIMSS 2019 (9. trinn) for å se om endringer i hvor ofte elevene snakker norsk hjemme, kan forklare nedgangen i naturfagprestasjoner. Resultatet fra kvasi-longitudinell metodisk tilnærming med medieringsmodellering viser at språk forklarer noe av nedgangen i naturfagprestasjoner, men at språk ikke er en hovedgrunn til den observerte nedgangen i naturfagprestasjoner.

Nøkkelord TIMSS | naturfag | språk i hjemmet | trendanalyser | prestasjoner

\begin{abstract}
Language is an important factor in an equity perspective. This study uses data from TIMSS 2015 and TIMSS 2019 (9th grade) to see if changes in how often students speak Norwegian at home can explain the decline in science performance. The results from a quasi-longitudinal approach with mediation modeling, indicates that language explains some of the decline in science performance, but that language is not a major reason for the observed decline in science performance.
\end{abstract}

Keywords TIMSS I science I language at home I trend analyses I achievement 


\subsection{INNLEDNING}

Paying more attention to language is one of the most important acts that can be done to improve the quality of science education. (Wellington \& Osborne, 2001)

Naturfaglig kompetanse og forståelse av naturfaglig språk er viktig for aktiv deltakelse i samfunnsdebatten i et stadig mer teknologisk og komplisert samfunn. Naturfaglig allmenndannelse er et viktig mål for opplæringen (Sjøberg, 2009), og det naturfaglige språket bidrar i stor grad til dette (Mork \& Erlien, 2017). Nøkkelen til å forstå og vise forståelse i naturfaget ligger i å beherske fagets språk (Mork \& Erlien, 2017). Språket er samtidig en barriere for mange elever for å lære faget (Wellington \& Osborne, 2001). For elever som snakker et annet språk hjemme enn undervisningsspråket på skolen, kan det å lære det naturfaglige språket by på ekstra utfordringer. I et likeverdsperspektiv spiller derfor språkkunnskaper en viktig rolle. Likeverdstanken er grunnleggende i den norske skolen (Meld. St.16 (2006-2007)), og kompensasjonstiltak skal kompensere for utfordringer knyttet til skolespråket (NOU 2010: 7). Forsterket språkopplæring har vært fremtredende i norsk skole i mange år (se tidligere læreplaner som M87, LK06) og, for eksempel, Sommerskolen i Oslo (2021) har kurs spesielt tilrettelagt for minoritetsspråklige elever. Videre har det vært mange satsinger på naturfagopplæring over lengre tid (for eksempel Naturfagssenterets «Forskerføtter og leserøtter»).

Til tross for satsinger på både språkopplæring og naturfag viser den internasjonale storskalaundersøkelsen TIMSS 2019 en nedgang i naturfagprestasjoner for 9.trinnselever under de siste årene (Kaarstein et al., 2020). Kunnskap om hva denne nedgangen kan skyldes, er viktig sett i et utdannings- og læringsperspektiv samt i et likeverdsperspektiv. Uten empiri er det vanskelig å vite hvilke tiltak som kan være effektive for å motvirke ytterligere nedgang i naturfagkompetansen til norske elever. Utdanningspolitikk bør basere seg på evidensbasert forskning med representative utvalg på nasjonalt nivå. For å kunne si noe om kausale årsaker til endringer av elevers prestasjoner og effekten av ulike tiltak kreves randomiserte kontrollerte studier (Cartwright, 2010). Dette er ikke mulig å gjøre i praksis for et representativt utvalg av norske elever, men det finnes noen kausale metoder som kan brukes til å undersøke hvorvidt endringer i én variabel har en effekt på endringer i elevers prestasjoner (Gustafsson \& Nilsen, i trykk; Nilsen \& Gustafsson, 2014). I dette kapitlet benyttes et kvasi-longitudinelt design, med data fra et representativt utvalg av norske elever knyttet til TIMSS 2015 og TIMSS 2019, for å undersøke om noe av nedgangen i naturfagprestasjoner er relatert til endringer i elevers språkkunnskaper. 


\subsection{VIKTIGHETEN AV SPRÅKKUNNSKAPER}

\subsubsection{Språkkunnskaper}

Språk er et viktig verktøy i all undervisning og læring. Uten språk er det vanskelig å formidle ny kunnskap, uttrykke forståelse, diskutere og reflektere, eller å delta i diskusjoner og ha meninger om debatter i samfunnet. Nøkkelen til å forstå og å vise forståelse i et fag ligger derfor i å beherske fagets språk (Mork \& Erlien, 2017). Å lære det naturfaglige språket er av den grunn en viktig del av det å lære naturfag (Wellington \& Osborne, 2001). Uten gode språkkunnskaper vil læringsutbyttet i faget reduseres betraktelig.

Å beherske og å lære seg det naturfaglige språket kan være utfordrende for elever (Wellington \& Osborne, 2001). Dette skyldes at det naturfaglige språket og hverdagsspråk skiller seg mye fra hverandre (Mortimer \& Scott, 2003). Hverdagsspråk er uformelt og preges ikke av fagspråkets presiserende og nyanserende terminologi, klassifiseringer, abstraksjoner og definisjoner. Det naturfaglige språket har et rikt, spesialisert vokabular av vitenskapelige eller tekniske ord og begreper som har mer eksakt mening eller definisjon enn hverdagsspråket (Wellington \& Osborne, 2001). Videre har fagspråket en større tetthet av informasjon, objektivitet og et høyere abstraksjonsnivå enn hverdagsspråk (Fang, 2005; Mork \& Erlien, 2017). Et kjennetegn på naturfaglig språk er nominalisering, som betyr at en beskrivelse av noe som skjer, blir omgjort til et begrep uten tid, handling og aktør (Knain, 2005). Alt dette gjør fagspråket - og dermed naturfaget - vanskeligere å forstå (Skaftun et al., 2014, s. 117). Det er viktig å bevisst arbeide aktivt med begreper tilknyttet naturfaget for å hjelpe elevene til forståelse, men man må ikke glemme at de ikke-tekniske ordene kan være like problematiske (Wellington \& Osborne, 2001). Begreper som blir brukt i det daglige, kan ha en mer presis eller annen betydning i naturfaglig sammenheng. Eksempler på slike ord kan være vekt, energi, kraft og arbeid.

Språkvansker kan være et skjult handikap. Det er ikke alltid så synlig når individet strever med å uttrykke seg, forstå eller bruke språket (Sæverud et al., 2011). For elever med redusert ordforråd i forhold til sine jevnaldrende kan utfordringene med å tilegne seg et fagspråk være enda større (Sæverud et al., 2011). Minoritetselever lærer oftest et hverdagsspråk først, og deretter akademiske begreper (NOU 2010: 7). Det er estimert at de vil trenge 5-7 år før de behersker akademiske ferdigheter i sitt nye språk (Bakken 2007; Cummins 2000), men å beherske et hverdagsspråk er ikke nødvendigvis tilstrekkelig for å kunne utvikle akademiske ferdigheter i språket (NOU 2010: 7). En elev som stadig møter ord og begreper som er ukjente, vil ha vanskeligheter med å forstå innholdet i et fag. For å forstå faget 
er derfor begrepslæring viktig, i tillegg til forståelse av hverdagsord og deres mening i faglig sammenheng.

\subsubsection{Likeverd}

Det norske utdanningssystemet er tuftet på grunntanken om likeverd (Frønes et al., 2020; Nilsen et al., 2018; Opplæringslova, 1998). Alle elever skal ha samme rett til utdanning, uavhengig av «hjemmebakgrunn, kjønn, bosted og etnisitet» (Meld. St.16 (2006-2007)). Det er en forventning om kun små forskjeller i spredningen av elevenes prestasjoner (Strietholt, 2014) slik at skolen oppfyller sitt mål om å bidra til utjevning av sosiale forskjeller (Meld. St.16 (2006-2007)).

Sammenlignet med andre land som deltar i internasjonale storskalaundersøkelser, som TIMSS og PISA, er effekten av elevenes sosioøkonomiske bakgrunn på prestasjonene mindre uttalt i Norge (OECD, 2016; Olsen \& Björnsson, 2018). En relativt lavere andel av forskjellene mellom norske elever kan knyttes til hjemmebakgrunn eller hvilken skole de går på (Olsen \& Björnsson, 2018), men disse forskjellene ser ut til å være økende (Nilsen et al., 2018; OECD, 2016). Generelt har norske elever svært høye verdier for målene for sosioøkonomisk bakgrunn i de internasjonale storskalaundersøkelsene (Olsen \& Björnsson, 2018), men siden 2011 har andelen barn som tilhører husholdninger med vedvarende lave inntekter, økt (Epland \& Normann, 2021). I 2011 og 2015 tilhørte henholdsvis 7,7 og 10 prosent av alle barn denne gruppen. I 2019 var andelen kommet opp i 11,7 prosent av alle barn (Epland \& Normann, 2021). Barn med innvandrerbakgrunn er overrepresentert og utgjorde i 2015 53,4 prosent av alle barn i denne gruppen, hvilket betyr at 38 prosent av alle innvandrerbarn i Norge tilhørte en lavinntektsfamilie det året (Epland \& Kirkeberg, 2017). I 2019 er tilsvarende andel 58,8 prosent av alle barna i denne gruppen, som betyr at i 2019 tilhørte 39,1 prosent av alle innvandrerbarn i Norge en lavinntektsfamilie (Epland \& Normann, 2021).

En inkluderende skole med mål om å bidra til utjevning har behov for kompensasjonstiltak (NOU 2010: 7). Det kan være nødvendig «å ha en beredskap for å kompensere for de utfordringene minoritetsspråklige elever står overfor når skolespråket er et annet enn det de møter i hjemmet og nærmiljøet» (NOU 2010: 7). I den nordiske modellen er likeverd høyt verdsatt, og i generell del av læreplanen er det et uttalt mål at «større likhet i resultat skapes gjennom ulikhet i den innsats som rettes mot den enkelte elev» (Kunnskapsdepartementet, 2017; Meld. St.16 (2006-2007)). I praksis ses dette gjennom blant annet større tildelinger til skoler i områder med generelt lavere sosioøkonomisk status (jf. Fordelingsmodellen for Oslo; Nilsen et al., 2018). Høyt likeverd har vist seg å fremme læring (Creemers \& Kyriakides, 2012). 
Språk er en viktig faktor i et likeverdsperspektiv. For å kunne delta aktivt i undervisningen og i samfunnet må minoritetselevene beherske et visst nivå av majoritetsspråket (Baker \& Wright, 2017). Selv om eleven kan kommunisere godt på et språk i hverdagen, er det noe helt annet å bruke språket på et akademisk nivå, slik det brukes i skolen. Tospråklige som har akademiske ferdigheter på sitt førstespråk, vil dra nytte av dette i sine akademiske ferdigheter i sitt andrespråk (jf. «Common underlying proficiency»-modellen; Baker \& Wright, 2017; Cummins \& Swain, 1986). Begrepsforståelsen kan overføres mellom språkene (Cummins, 2009), men ifølge toterskelteorien krever en slik overføring et visst nivå av språkbeherskelse (Baker \& Wright, 2017; Cummins \& Swain, 1986).

\subsubsection{Tidligere forskning på sammenheng mellom språk og elevers prestasjoner}

Naturfaglig kunnskap er nært knyttet til lese- og skriveferdigheter (Norris \& Phillips, 2003). Språkkunnskaper kan være den største hindringen for elevers læring i naturfag (Wellington \& Osborne, 2001). Det naturfaglige språket består av presiserende og nyanserende terminologi, klassifiseringer, abstraksjoner og definisjoner. Fagkunnskap og det spesialiserte fagspråket i naturfag henger sammen, og det er vanskelig å formidle fagkunnskapen uten fagspråket (Busch \& Ralle, 2012). Hvis elevene ikke forstår språkbruken i naturfaget, så forsvinner grunnlaget for faglig forståelse (Haug \& Mork, 2018). Det er selvfølgelig mulig å lære naturfag uten å bruke mange fagord, men det er begrenset hvor mye som kan læres i naturfaget, uten god kjennskap til det naturfaglige fagspråket (Mork \& Erlien, 2017).

Mange minoritetselever har vanskeligheter med å forstå språkbruken i naturfag (Parszyk, 1999). Dette påvirker utbyttet av læringssituasjonen i faget. Minoritetselever som snakker et annet språk hjemme, og som besitter begrensede språkkunnskaper i undervisningsspråket, opplever vanskeligheter med å beherske naturfaget. Flernivå hierarkiske regresjonsanalyser viser at språket i hjemmet og språkkunnskaper i undervisningsspråket spiller en viktig rolle i elevers naturfagprestasjoner (Van Laere et al., 2014). Elever som behersker undervisningsspråket på et høyt nivå, presterer bedre i naturfag enn elever som ikke behersker undervisningsspråket på det samme høye nivået (Van Laere et al., 2014). Videre viser resultater fra TIMSS 2015 at det er en positiv sammenheng mellom naturfagprestasjoner og språkbruk i hjemmet for norske elever på 9. trinn, med en standardisert regresjonskoeffisient på 0,39 (p-verdi < 0,05) (Nilsen \& Bergem, 2016).

I Norge er det kun små forskjeller mellom kjønnene i realfagprestasjoner, men jenter leser betydelig bedre enn gutter på ungdomstrinnet (Olsen \& Björnsson, 
2018). Kjønnsforskjellene i lesing er blant de høyeste i OECD-landene (Frønes, 2016), og har holdt seg på samme nivå etter at internasjonale storskalaundersøkelser som PISA ble gjennomført elektronisk i stedet for på papir (Eriksen \& Narvhus, 2013; Støle \& Schwippert, 2017). Jenter er bedre på abstrakt språkbruk (Burmana et al., 2008), men gutter viser som regel større spredning i prestasjoner enn jenter (Lehre et al., 2009). Den kognitive profilen for gutter og jenter viser likt generelt evnenivå, men jenter har i gjennomsnitt bedre språklige evner enn gutter allerede fra ung alder (NOU 2019: 3). Forskjellen i lesning og skriving øker med alderen, og jenter engasjerer seg oftere mer enn gutter i språklige aktiviteter (NOU 2019: 3).

Norske data fra TIMSS 2015 og TIMSS 2019 viser en markant nedgang i naturfagprestasjonene på 9. trinn (Kaarstein et al., 2020), og naturfagprestasjoner påvirkes blant annet av språkkunnskaper (Kaarstein et al., 2020; Nilsen \& Bergem, 2016). Dette kapitlet undersøker om endringer i hvor ofte elever snakker norsk hjemme, kan ha hatt innflytelse på denne nedgangen. Hvis det er en slik sammenheng, så kan en forsterket språkopplæring av minoritetsspråklige elever kanskje bidra til økt forståelse av naturfaget og naturfaglig språk for elevene det gjelder. Dette igjen kan bidra til at gapet mellom elevers prestasjoner i naturfag reduseres.

\subsection{METODE}

\subsubsection{Om data og utvalg}

Den internasjonal storskalaundersøkelsen Trends in International Mathematics and Science Study (TIMSS) måler elevers kompetanse i naturfag og matematikk på 5. og 9. trinn. For å kunne se på konteksten som utdanningen skjer innenfor, inkluderer undersøkelsen spørreskjemaer til elever, foreldre, lærere og skoleledere. Første tverrsnittsundersøkelse ble gjennomført i 1995, og den blir gjentatt hvert 4. år. For mer om TIMSS-undersøkelsen, se kapittel 1 i denne antologien eller timss.no.

I dette kapitlet analyseres norske data hentet fra TIMSS 2015 og TIMSS 2019. Datasettet består av et representativt utvalg av elever på 9.trinn (2015: n = 4697; 2019: $\mathrm{n}$ = 4575). Gjennomsnittsalderen til elevene på undersøkelsestidspunktene var 14,7 år, og andelen gutter og jenter er jevnt fordelt (Fishbein et al., 2021).

\subsubsection{Variabler og konstrukter}

For å se på om det er endringer i hvor ofte elevene snakker norsk hjemme, og om eventuelle endringer kan forklare nedgangen i naturfagprestasjoner på 9. trinn, brukes variabler fra elevskjema. Elevenes svar på hvor ofte de snakker norsk 
hjemme, ses i sammenheng med elevenes prestasjoner i naturfag kontrollert for kjønn. Elevenes sosioøkonomiske status har ikke endret seg vesentlig fra 2015 til 2019 og er derfor ikke inkludert som kontrollvariabel i denne analysen. Tabell 7.1 viser en mer detaljert beskrivelse av konstrukter og variabler som inngår $i$ analysen.

Tabell 7.1 Konstrukter og variabler som inngår i analysen

\begin{tabular}{|l|l|l|c|}
\hline Variabel & Spørsmål & Skala & $\begin{array}{l}\text { Antall svar- } \\
\text { alternativer }\end{array}$ \\
\hline $\begin{array}{l}\text { Språk } \\
\text { hjemme }\end{array}$ & Hvor ofte snakker du norsk hjemme? & $\begin{array}{l}\text { Alltid } \\
\text { Nesten alltid } \\
\text { Av og til } \\
\text { Aldri }\end{array}$ & 4 \\
\hline $\begin{array}{l}\text { Prestasjon i } \\
\text { naturfag }\end{array}$ & $\begin{array}{l}220 \text { oppgaver, hvorav cirka halvparten } \\
\text { er åpne oppgaver og den andre halv- } \\
\text { parten er flervalgsoppgaver. }\end{array}$ & $\begin{array}{l}\text { Jente (kodet til 0) } \\
\text { Gutt (kodet til 1) }\end{array}$ & \\
\hline Kjønn & & & \\
\hline
\end{tabular}

\subsubsection{Analysemetode/analyserammeverk}

TIMSS er en trendundersøkelse hvis design og psykometriske metoder gjør det mulig å beskrive og analysere utviklingstrekk av utdanningssystemer over tid (Olsen \& Björnsson, 2018). Dataene fra hver syklus skaleres og settes på en fast skala med midtpunkt på 500 poeng og standardavvik på 100. Den faste skalaen fører til at elevenes faglige prestasjoner kan sammenlignes over tid.

For å undersøke om det er endringer i hvor ofte elevene snakker norsk hjemme, blir datasettet fra TIMSS 2015 slått sammen med datasettet fra TIMSS 2019. Undersøkelsestidspunktene gir opphav til en hjelpevariabel for tid, kodet til 0 for 2015 og til 1 for 2019. Dette gir et kvasi-longitudinelt design som muliggjør mer robuste slutninger enn slutninger basert på en tverrsnittsundersøkelse (Nilsen \& Gustafsson, 2014). Medieringsmodeller undersøker om endringer i elevenes forståelse og bruk av norsk har en sammenheng med endringer i naturfagprestasjoner over tid (figur 7.1). Forutsetninger for medieringsmodellen er at variabelen som måler hvor ofte elevene snakker norsk hjemme, har endret seg fra 2015 til 2019, og at den har en signifikant påvirkning på naturfagprestasjoner. For å se nærmere på dette ble strukturell ligningsmodellering tatt i bruk. Bekreftende faktoranalyser (CFA) (Brown, 2015) ble benyttet for å undersøke validiteten og reliabiliteten til latente variabler. For å se på eventuelle kjønnsforskjeller ble det kjørt en multigroup strukturell ligningsmodellering. 


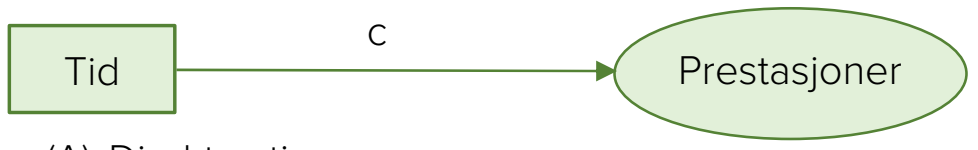

(A) Direkte sti



Figur 7.1 Medieringsmodell for den (A) direkte og (B) indirekte effekten av tid på prestasjoner.

Figuren viser den direkte effekten av tid på språk (a), språk på prestasjoner (b) og tid på prestasjoner (c), samt den indirekte effekten av tid på prestasjoner (c').

Analysene ble gjort med strukturell ligningsmodellering i Mplus versjon 8.0 (Muthén \& Muthén, 1998-2017). Programvaren estimerer regresjonskoeffisienter på elev- og skolenivå, ivaretar korrekt bruk av de fem plausible verdiene for naturfagprestasjoner (Rutkowski et al., 2013), og håndterer manglende verdier for en eller flere variabler (MLR, robust maximum likelihood; Puthenpura \& Sinha, 1986). Videre estimerer programmet hvor godt en modell er tilpasset dataene (Hox \& Roberts, 2011). For å ta hensyn til det hierarkiske designet til TIMSS, hvor elever tilhører klasser som tilhører skoler, ble TYPE = COMPLEX benyttet, og dataene ble gruppert på skolenivå. Dette er basert på antagelsen at det er større forskjeller mellom skoler enn mellom klasser når det gjelder hvor ofte elever snakker norsk hjemme.

\subsection{RESULTATER}

Fra TIMSS 2015 til TIMSS 2019 er det en signifikant nedgang i naturfagprestasjoner for norske ungdomsskoleelever (Kaarstein et al., 2020). Nedgangen i prestasjoner er på 13,18 poeng ( $p$-verdi < 0,001) og tilsvarer den totale effekten i modellen (tabell 7.2). Den totale effekten består av en direkte og en indirekte effekt av tid på prestasjoner, på henholdsvis -10.89 poeng ( $\mathrm{p}$-verdi $<0,001)$ og $-2,29$ poeng $(\mathrm{p}$ - 
verdi < 0,001) (tabell 7.2; figur 7.2). De negative verdiene viser at effekten bidrar negativt til prestasjonene, med andre ord: bidrar til nedgangen i naturfagprestasjoner fra 2015 til 2019. Noe av denne nedgangen kan forklares av hvor ofte elevene snakker norsk i hjemmet. Språkkunnskaper (stiplet linje i figur 7.2B) forklarer cirka 2 poeng av de cirka 13 poengene nedgang i naturfagprestasjoner fra 2015 til 2019 (p-verdi $<0,001)$. Selve modellen forklarer 3,5 prosent av variansen $\left(R^{2}\right)$.



(A) Direkte sti



(B) Mediert sti

Figur 7.2 Resultater for medieringsmodellen for $(A)$ den direkte og $(B)$ den indirekte effekten av tid på prestasjoner.

Figuren viser den direkte effekten av tid på språk (a), språk på prestasjoner (b) og tid på prestasjoner (c), og den indirekte effekten av tid på prestasjoner (c'). P-verdi $<0.001$ for alle variablene i modellen. $\mathrm{N}=9272$.

Tabell 7.2 Oversikt over direkte og indirekte effekt av de latente variablene i modellen

\begin{tabular}{|c|c|c|c|c|c|}
\hline & a & b & c & $c^{\prime}$ & \\
\hline Variabel & $\begin{array}{l}\text { Direkte effekt av } \\
\text { tiden på språk- } \\
\text { kunnskaper }\end{array}$ & $\begin{array}{l}\text { Direkte effekt av } \\
\text { språkkunnskaper } \\
\text { på prestasjoner }\end{array}$ & $\begin{array}{c}\text { Direkte effekt } \\
\text { av tiden på } \\
\text { prestasjoner }\end{array}$ & $\begin{array}{c}\text { Indirekte effekt } \\
\text { av tid på presta- } \\
\text { sjoner }\end{array}$ & $\begin{array}{c}\text { Total effekt } \\
\text { (nedgang i } \\
\text { prestasjoner) }\end{array}$ \\
\hline $\begin{array}{l}\text { Språk (Hvor ofte } \\
\text { det snakkes } \\
\text { norsk hjemme) }\end{array}$ & $-0,11(0,03)^{* *}$ & $21,49(1,84)^{\star *}$ & $-10,89(3,90)^{*}$ & $-2,29(0,65)^{\star *}$ & $-13,18(4,11)^{\star *}$ \\
\hline $\begin{array}{l}\text { Språk (Hvor ofte } \\
\text { det snakkes } \\
\text { norsk hjemme) } \\
\text { Standardisert }\end{array}$ & $-0,08(0,02)^{* *}$ & $0,17(0,02)^{\star *}$ & $-0,06(0,02)^{\star}$ & $-\mathbf{0 , 0 1}(0,00)^{\star *}$ & $-0,08(0,02)^{* *}$ \\
\hline
\end{tabular}

Regresjonskoeffesienter (SE). * Signifikansnivå p =0,005; ** Signifikansnivå $p<0,001$. 
Hvor ofte elever snakker norsk i hjemmet, medierer effekten av tid på prestasjoner (figur 7.2). Medieringsmodellen viser at tid har en negativ effekt på språk $(-0,11$; p-verdi $=0,005)$. Andelen ungdomsskoleelever som alltid snakker norsk i hjemmet, er altså noe redusert fra 2015 til 2019.

Videre viser modellen at det er en sammenheng mellom hvor ofte en elev snakker norsk i hjemmet, og deres prestasjoner i naturfag. Økt mengde med norsk i hjemmet assosieres med bedre prestasjoner. For hvert hakk opp på TIMSS-skalaen over hvor mye norsk som snakkes i hjemmet, øker naturfagprestasjonene i gjennomsnitt med 21,49 poeng ( $\mathrm{p}$-verdi $=0,001$ ). Dette tilsvarer nesten 1 års skolegang (Kaarstein et al., 2020).

Tabell 7.3 Oversikt over direkte og indirekte effekt av de latente variablene i modellen for gutter og jenter

\begin{tabular}{|c|c|c|c|c|c|}
\hline & a & b & c & $c^{\prime}$ & \\
\hline Variabel & $\begin{array}{c}\text { Direkte effekt av } \\
\text { tiden på språk- } \\
\text { kunnskaper }\end{array}$ & $\begin{array}{c}\text { Direkte effekt av } \\
\text { språkkunnska- } \\
\text { per på prestasjo- } \\
\text { ner }\end{array}$ & $\begin{array}{c}\text { Direkte } \\
\text { effekt av } \\
\text { tiden på pre- } \\
\text { stasjoner }\end{array}$ & $\begin{array}{l}\text { Indirekte } \\
\text { effekt av tid } \\
\text { på presta- } \\
\text { sjoner }\end{array}$ & $\begin{array}{l}\text { Total effekt } \\
\text { (nedgang i } \\
\text { prestasjoner) }\end{array}$ \\
\hline $\begin{array}{l}\text { Språk } \\
\text { (Jenter) } \\
\mathrm{N}=4242\end{array}$ & $-0,08(0,04)^{\star}$ & $22,80(2,92)^{\star \star}$ & $-5,71(5,33)$ & $-\mathbf{1 , 8 3}(0,88)^{\star}$ & $-7,55(5,60)$ \\
\hline $\begin{array}{l}\text { Språk } \\
\text { (Gutter) } \\
\mathrm{N}=3708\end{array}$ & $-0,15(0,04)^{\star *}$ & $19,37(2,56)^{\star *}$ & $-14,19(5,40)^{*}$ & $-2,81(0,82)^{\star *}$ & $-17,00(5,60)^{\star}$ \\
\hline
\end{tabular}

Regresjonskoeffesienter (SE). * Signifikansnivå $p=0,005 ;{ }^{* *}$ Signifikansnivå $p<0,001$.

Ved kontroll for eventuelle kjønnsforskjeller viser den indirekte effekten av tid på prestasjoner for jenter og gutter henholdsvis $-1,83$ ( $\mathrm{p}$-verdi $=0,038$ ) og $-2,81$ ( $\mathrm{p}$ verdi $=0,001)$. Selv om dette kun er små forskjeller, viser det at hvor ofte eleven snakker norsk i hjemmet, forklarer litt mer av nedgangen i naturfagprestasjoner for gutter enn for jenter.

\subsection{DISKUSJON}

\subsubsection{Kort oppsummering av funn}

Språkkunnskaper er med på å forklare noe av nedgangen i naturfagprestasjoner fra 2015 til 2019, men dette er ikke en hovedgrunn til nedgangen. Hvor ofte det snakkes norsk i hjemmet, medierer endringer i prestasjoner over tid og forklarer cirka 2 poeng av de 13 poengene nedgang i naturfagprestasjoner for 9 . trinn fra TIMSS 
2015 til TIMSS 2019. Når det kontrolleres for eventuelle kjønnsforskjeller, kan det se ut til at hvor ofte eleven snakker norsk i hjemmet, forklarer litt mer av nedgangen i naturfagprestasjoner for gutter ( 2,8 poeng) enn for jenter ( 1,8 poeng). Sammenhengen mellom hvor ofte en elev snakker norsk i hjemmet, og elevens naturfagprestasjoner, vises ved at økt mengde med norsk i hjemmet assosieres med bedre prestasjoner. For hvert hakk opp på TIMSS-skalaen over hvor ofte norsk snakkes i hjemmet, øker naturfagprestasjonene i gjennomsnitt med noe som tilsvarer 1 års skolegang.

\subsubsection{Diskusjon av funn i lys av teori}

Medieringsmodellen viser at tid har en negativ effekt på språk $(-0,11 ; \mathrm{p}$-verdi = 0,005), hvilket antyder at andelen ungdomsskoleelever som alltid snakker norsk i hjemmet, er noe redusert fra 2015 til 2019. Dette er i overensstemmelse med data fra SSB som viser at antallet etnisk norske har vært mer eller mindre stabilt i perioden 2011-2020, mens andelen innvandrere har økt noe i samme tidsrom, fra 500500 i 2011 til 790497 i 2020 (SSB). I de samme årene som TIMSS-undersøkelsene, i 2015 og i 2019, utgjorde befolkningsandelen innvandrere (både utenlandske foreldre og besteforeldre) henholdsvis 15,6 prosent og 17,7 prosent av den totale befolkningen i Norge. Befolkningsandelen av norskfødte med både norske foreldre og besteforeldre ble redusert fra 75,7 prosent i 2015 til 72.9 prosent i 2019 (SSB). Den resterende andelen av befolkningen består av personer der en eller flere av foreldre eller besteforeldre ikke er etnisk norske. I samsvar med dette er det logisk å anta at andelen skoleelever som alltid snakker norsk hjemme, har blitt noe redusert fra 2015 til 2019.

I et likeverdsperspektiv er språk en viktig faktor. Minoritetselevene må beherske et visst nivå av majoritetsspråket for å kunne delta aktivt i undervisningen (Baker \& Wright, 2017). Uten gode språkkunnskaper vil læringsutbyttet i naturfaget reduseres betraktelig. Analysene i dette kapitlet peker på en sammenheng mellom hvor ofte en elev snakker norsk i hjemmet, og elevens prestasjoner i naturfag. Den direkte effekten av språk på prestasjoner i naturfag er forholdsvis stor (21.49; pverdi < 0.001). Den gjennomsnittlige forskjellen mellom elever på to tilgrensende nivåer i firetrinnsskalaen (Alltid - Nesten alltid - Av og til - Aldri) over hvor mye norsk som snakkes i hjemmet, tilsvarer nesten ett års skolegang (25 poeng på TIMSS-skalaen tilsvarer et skoleår for norske elever på 9.trinn; Kaarstein et al., 2020). Dette er i samsvar med tidligere funn om at språkkunnskaper påvirker prestasjoner i naturfag (for eksempel Kaarstein et al., 2020; Nilsen \& Bergem, 2016; Van Laere et al., 2014). Hvis elevene ikke forstår språkbruken i naturfaget, så for- 
svinner grunnlaget for faglig forståelse (Haug \& Mork, 2018). Uten god kjennskap til det naturfaglige språket er det begrenset hvor mye som kan læres i naturfaget. Nøkkelen til å forstå, og å vise forståelse i et fag, ligger i å beherske fagets språk (Mork \& Erlien, 2017). Å lære det naturfaglige språket er derfor en viktig del av det å lære naturfag (Wellington \& Osborne, 2001), men det tar år å beherske akademiske ferdigheter i et nytt språk (Bakken, 2007; Cummins, 2000). Uten gode språkkunnskaper vil læringsutbyttet i faget reduseres betraktelig, noe som også analysene i dette kapitlet understøtter.

Videre viser analysene at hvor ofte norsk snakkes i hjemmet (språk), medierer endringer i prestasjoner over tid. Språk forklarer dermed noe av nedgangen i naturfagprestasjoner for 9. trinn fra TIMSS 2015 til TIMSS 2019. Dette var forventet da effekten av språk på prestasjoner er forholdsvis stor, og andelen elever som alltid snakker norsk hjemme, ble noe redusert i perioden. Videre tilhørte 39,1 prosent av alle innvandrerbarn i Norge en lavinntektsfamilie i 2019 (Epland \& Normann, 2021). Lav sosioøkonomisk status er korrelert med prestasjoner og ligger typisk på 0,3 på individnivå (Sirin, 2005; White, 1982), men effekten av elevenes sosioøkonomiske bakgrunn på prestasjonene er mindre uttalt i Norge enn andre land (OECD, 2016; Olsen \& Björnsson, 2018). Lav sosioøkonomisk status, og hvor ofte en elev snakker norsk i hjemmet, er korrelert, og begge bidrar mest sannsynlig til lavere gjennomsnittsprestasjoner i naturfag for elever som snakker lite norsk hjemme. Det er viktig å huske på at resultatene er gjennomsnittlige, så det vil finnes elever som alltid snakker norsk hjemme, som er lavtpresterende, og elever som nesten aldri snakker norsk hjemme, som er høytpresterende.

Et interessant funn er at hvor ofte man snakker norsk i hjemmet, forklarer litt mer av nedgangen i naturfagprestasjoner for gutter $(-2,81$, p-verdi $=0,001)$ enn tilsvarende for jenter $(-1,83$, p-verdi $=0,038)$. Forskjellen mellom kjønnene er ikke stor, og dette passer med andre studier som viser at det kun er små forskjeller mellom kjønnene i realfagprestasjoner i Norge (Olsen \& Björnsson, 2018). Kanskje har jenter nytte av at de oftere engasjerer seg mer enn gutter i språklige aktiviteter (NOU 2019: 3). Videre er jenter noe bedre på abstrakt språkbruk enn gutter (Burmana et al., 2008) og har i gjennomsnitt bedre språklige evner enn gutter allerede fra ung alder (NOU 2019: 3). Jenter er også betydelig bedre lesere enn gutter på ungdomstrinnet (Olsen \& Björnsson, 2018). Naturfaglig kunnskap er nært knyttet til lese- og skriveferdigheter (Norris \& Phillips, 2003). Språkkunnskaper kan derfor være den største hindringen for elevers læring i naturfag (Wellington \& Osborne, 2001). Det er verdt å minne om at den kognitive profilen for gutter og jenter viser likt generelt evnenivå (NOU 2019: 3), men interessen eller eksponeringen for norsk språk kan være noe forskjellig for gutter og jenter. 


\subsubsection{Begrensninger ved studien}

TIMSS er en tverrsnittsundersøkelse med et representativt utvalg av elever som gjennomføres hvert fjerde år (Kaarstein et al., 2020). Styrken i undersøkelsen er at skalaene for elevenes prestasjoner er lenket over tid og dermed tilfører robust empiri som gjør at det er mulig å undersøke for eksempel sammenhengen mellom språk og naturfagprestasjoner (Nilsen et al., 2018). Analysene i dette kapitlet benytter et kvasi-longitudinelt design som muliggøør mer robuste slutninger enn slutninger basert på kun en tverrsnittsundersøkelse (Nilsen \& Gustafsson, 2014). En longitudinell studie, hvor de samme elevene følges over lang tid, ville vært mer robust, men en longitudinell studie med et representativt utvalg er svært ressurskrevende.

Analysene i dette kapitlet er basert på en variabel i spørreskjema tilknyttet både TIMSS 2015 og TIMSS 2019. Elevene ble bedt om å svare på «hvor ofte snakker du norsk hjemme» og hadde fire svaralternativer (Alltid - Nesten alltid - Av og til Aldri) å velge i. Selvrapportering innebærer alltid en risiko for feilrapportering, men resultatene er i samsvar med tidligere funn om at språkkunnskaper påvirker prestasjoner i naturfag (for eksempel Kaarstein et al., 2020; Nilsen \& Bergem, 2016; Van Laere et al., 2014). Det er derfor ikke grunn til å anta at det er større problemer med selvrapporteringen i denne TIMSS-variabelen enn tilsvarende variabler $\mathrm{i}$ andre studier.

Målet for hvor ofte en elev snakker norsk hjemme, mangler informasjon om både hvor lang tid eleven har oppholdt seg i landet, og hvor lenge eleven har gått på norsk skole. En elev som har oppholdt seg kort tid i landet, vil nødvendigvis ha større problemer med å løse naturfagoppgaver enn en elev som har vært eksponert for norsk språk over et lengre tidsrom. I TIMSS-undersøkelsen blir dette tatt hensyn til ved at elever som har fått mindre enn et års undervisning i norsk, blir fritatt fra undersøkelsen (Martin et al., 2016).

\subsubsection{Bidrag, implikasjoner og videre forskning}

Analysene i dette kapitlet viser at hvor ofte undervisningsspråket snakkes i hjemmet, har innflytelse på prestasjoner i naturfag. Dette er i samsvar med tidligere forskning (Kaarstein et al., 2020; Nilsen \& Bergem, 2016; Van Laere et al., 2014). Bidraget til dette kapitlet er at undersøkelsen benytter et kvasi-longitudinelt design på et representativt utvalg av elever på 9. trinn. Designet muliggjør mer robuste slutninger enn slutninger basert på kun en tverrsnittsundersøkelse (Nilsen \& Gustafsson, 2014). 
Språk kan være den største hindringen for elevers læring i naturfag (Wellington \& Osborne, 2001). Det vil derfor være viktig å jobbe med både fagspråk og hverdagsspråk slik at elevene får best mulig læringsutbytte i faget. Elever som behersker undervisningsspråket på et høyt nivå, presterer bedre i naturfag enn elever som ikke behersker undervisningsspråket like godt (Van Laere et al., 2014). Det kan derfor være hensiktsmessig å satse på god opplæring og støtte i undervisningsspråket for flerspråklige elever. Det finnes gode initiativ allerede, bl.a. Naturfagssenterets «Forskerføtter og leserøtter» (Ødegaard et al., 2016) og Sommerskolen i Oslo (2021) sine kurs spesielt tilrettelagt for minoritetsspråklige: «Intensiv norskopplæring for nyankomne elever.»

Elever med svake ferdigheter i sitt førstespråk og i undervisningsspråket kan ha stor nytte av morsmålsundervisning. Det er vist at fonologiske ferdigheter og avkoding kan overføres mellom morsmål og andrespråk (Melby-Lervåg \& Lervåg, 2011). Begrepsforståelsen kan overføres mellom språkene (Cummins, 2009), men en slik overføring krever et visst nivå av språkbeherskelse (Baker \& Wright, 2017; Cummins \& Swain, 1986). Selv om morsmålsundervisning kan ha stor nytte både for den enkelte elev og for samfunnet generelt, gir metaanalyser liten støtte til morsmålsundervisning som et viktig redskap for å fremme bedre begrepsforståelse og leseforståelse på andrespråket (Melby-Lervåg \& Lervåg, 2011; 2014). Sammenhengen mellom morsmålsferdigheter og andrespråkstilegnelse, og hvilke tiltak som er hensiktsmessige for å øke forståelsen i et spesialisert fag som naturfag, bør belyses grundig med mer forskning. Det bør brukes longitudinelle, randomiserte kontrollerte studier for å undersøke effekten av språkforståelsesintervensjoner for å utvikle effektive programmer for andrespråklige.

\subsubsection{Konklusjon/sluttkommentar(er)}

Andelen 9.-trinnselever som snakker norsk hjemme, er noe redusert fra TIMSS 2015 til TIMSS 2019. Hvor ofte norsk snakkes i hjemmet, medierer endringer i prestasjoner over tid, men dette er ikke en hovedgrunn til nedgangen. At gjennomsnittsforskjellen i naturfagprestasjoner for elever som «av og til» og elever som «nesten alltid» snakker norsk hjemme, tilsvarer et skoleår, indikerer at det i et likeverdsperspektiv er viktig å ha gode tilbud om språkopplæring til minoritetselever på plass slik at disse får utnyttet sitt potensial. Naturfaglig kompetanse og forståelse av naturfaglig språk er viktig for aktiv deltakelse i et stadig mer teknologisk, komplisert samfunn som står overfor flere store utfordringer. 


\section{REFERANSER}

Baker, C. \& Wright, W.E. (2017). Foundations of bilingual education and bilingualism (6. utg.). Multilingual Matters.

Bakken, A. (2007). Virkninger av tilpasset språkopploring for minoritetsspråklige elever. En kunnskapsoversikt. (NOVA-rapport 10/07). Norsk institutt for forskning om oppvekst, velferd og aldring.

Brown, T.A. (2015). Methodology in the social sciences. Confirmatory factor analysis for applied research (2. utg.). The Guilford Press.

Burmana, D.D., Bitanc, T. \& Bootha, J.R. (2008). Sex differences in neural processing of language among children, Neuropsychologia 6(5), 1349-1362. https://doi.org/1349-62. 10.1016/j.neuropsychologia.2007.12.021.

Busch, H. \& Ralle, B. (2012). Special language competencies: Diagnosis and individual support. I S. Markic, I. Eilks \& B. Ralle (Red.), Issues of heterogeneity and cultural diversity in science education and science education research (s. 11-22). Shaker Verlag.

Cartwright, N. (2010). What are randomised controlled trials good for? Philos Stud 147, 59-70. https://doi.org/10.1007/s11098-009-9450-2

Creemers, B.P.M. \& Kyriakides, L. (2012). Improving quality in education: dynamic approaches to school improvement. Routledge.

Cummins, J. (2000). Language, power and pedagogy. Bilingual children in the crossfire. Multilingual Matters.

Cummins, J. (2009). Fundamental psycholinguistic and sociological principles underlying educational success for linguistic minority students. I T. Skutnabb-Kangas, R. Phillipson, A. K. Mohanty \& M. Panda (Red.), Social justice through multilingual education (s. 19-35). Multilingual Matters.

Cummins, J. \& Swain, M. (1986). Bilingualism in education: Aspects of theory, research and practice. Longman.

Epland, J. \& Kirkeberg, M.I. (2017). Ett av to barn tilhører en husholdning med vedvarende lavinntekt. https://www.ssb.no/inntekt-og-forbruk/artikler-og-publikasjoner/ett-av-ti-barntilhorer-en-husholdning-med-vedvarende-lavinntekt

Epland, J. \& Normann, T.M. (2021). 115000 barn i husholdning med vedvarende lavinntekt. https://www.ssb.no/inntekt-og-forbruk/artikler-og-publikasjoner/115000-barn-i-husholdning-med-vedvarende-lavinntekt

Eriksen, A \& Narvhus, E.K. (2013). Digital lesing. I M. Kjærnsli \& R.V. Olsen (Red.), Fortsatt en vei å gå. Norske elevers kompetanse i matematikk, naturfag og lesing i PISA 2012 (s. 201-218). Universitetsforlaget.

Fang, Z. (2005). Scientific literacy: A systemic functional linguistics perspective. Science Education, 89(2), 335-347. https://doi.org/10.1002/sce.20050

Fishbein, B., Foy, P. \& Yin, L. (2021). TIMSS 2019 User Guide for the International Database. Hentet fra Boston College, TIMSS \& PIRLS International Study Center website: https://timssandpirls.bc.edu/timss2019/international-database/

Frønes, T. (2016). Resultater i lesing. I M. Kjærnsli \& F. Jensen (Red.), Stø kurs. Norske elevers kompetanse i naturfag, matematikk og lesing i PISA 2015 (s. 136-171). Universitetsforlaget. 
Frønes, T.S., Pettersen, A., Radišić, J. \& Buchholtz, N. (2020). Equity, equality and diversity in the Nordic model of education-Contributions from large-scale studies. I T.S. Frønes, A. Pettersen, J. Radišić \& N. Buchholtz, (Red.) Equity, Equality and Diversity in the Nordic Model of Education (pp. 1-10). Springer, Cham.

Gustafsson, J-E. \& Nilsen, T. (in press) Methods of causal analysis with ILSA data. I International Handbook of Comparative Large-Scale Studies in Education. Springer International Handbooks of Education.

Haug, B.S. \& Mork, S. (2018). Språket er nøkkelen til å lære naturfag. Naturfag 1/18.

Hox, J. \& Roberts, J.K. (2011). Handbook of advanced multilevel analysis. Psychology Press.

Kaarstein, H., Radišić, J., Lehre, A.C., Nilsen, T. \& Bergem, O.K. (2020). TIMSS 2019. Kortrapport. Institutt for lærerutdanning og skoleforskning, Universitetet i Oslo.

Kirke- og undervisningsdepartementet (1987), Mønsterplan for grunnskolen 1987 (M87). Aschehoug \& Co (W. Nygaard).

Knain, E. (2005). Skriving i naturfag: Mellom tekst og natur. Nordina: Nordic Studies in Science Education, 1(1), 70-80. http://dx.doi.org/10.5617/nordina.467

Kunnskapsdepartementet (2017). Overordnet del av loereplanverket. https://www.udir.no/lk20/ overordnet-del/

Lehre, A.C., Lehre, K.P., Laake, P., Danbolt, N.C. (2009). Greater intrasex variability in males than in females is a fundamental aspect of gender differences in humans. Developmental Psychobiology, 51, 198-206. https://doi.org/10.1002/dev.20358

Meld. St. 16 (2006-2007). ... og ingen sto igjen. Tidlig innsats for livslang laering. http://www.regjeringen.no/nb/dep/kd/dok/regpubl/stmeld/2006-2007/stmeld-nr-16-2006-2007-.html

Martin, M.O., Mullis, I.V.S. \& Hooper, M. (Red.). (2016). Methods and Procedures in TIMSS 2015. Boston College, TIMSS \& PIRLS International Study Center http://timssandpirls.bc.edu/publications/timss/2015-methods.html

Melby-Lervåg, M. \& Lervåg, A. (2011). Hvilken betydning har morsmålferdigheter for utviklingen av leseforståelse og dets underliggende komponenter på andrespråket? En oppsummering av empirisk forsking, Norsk Pedagogisk Tidsskrift, 330-343.

Melby-Lervåg, M. \& Lervåg, A. (2014). Reading Comprehension and Its Underlying Components in Second-Language Learners: A Meta-Analysis of Studies Comparing First and SecondLanguage Learners. Psychological Bulletin, 140 (2), 409-433.

Mork, S. \& Erlien, W. (2017). Språk, tekst og kommunikasjon i naturfag. Universitetsforlaget.

Mortimer, E. \& Scott, P. (2003). Meaning Making in Secondary Science Classrooms? McGraw-Hill Education.

Muthén, L.K. \& Muthén, B.O. (1998-2017). Mplus user's guide (8 utgave). Muthén \& Muthén.

Nilsen, T., Björnsson, J.K. \& Olsen, R.V. (2018). Hvordan har likeverd i norsk skole endret seg se siste 20 årene? I: R.V. Olsen \& J.K. Björnsson (Red.), Tjue år med TIMSS og PISA i Norge. Trender og nye analyser. Universitetsforlaget. https://doi.org/10.18261/9788215030067-2018

Nilsen, T. \& Bergem, O.K. (2016). Hjemmebakgrunn. En likeverdig skole. I O.K. Bergem, H. Kaarstein \& T. Nilsen (Red.), Vi kan lykkes i realfag. Resultater og analyser fra TIMSS 2015. Universitetsforlaget. 
Nilsen, T. \& Gustafsson, J.-E. (2014). School emphasis on academic success: exploring changes in science performance in Norway between 2007 and 2011 employing two-level SEM. Educational Research and Evaluation, 20(4), 308-327.

Norris, S.P. \& Phillips, L.M. (2003). How literacy in its fundamental sense is central to scientific literacy. Science Education, 87(2), 224-240. https://doi.org/10.1002/sce.10066

NOU 2010: 7 (2010). Mangfold og mestring - Flerspråklige barn, unge og voksne i opplaringssystemet. Kunnskapsdepartementet. https://www.regjeringen.no/no/dokumenter/NOU-2010-7/ id606151/

NOU 2019: 3 (2019). Nye sjanser - bedre loring - Kjønnsforskjeller i skoleprestasjoner og utdanningsløp. Kunnskapsdepartementet. https://www.regjeringen.no/no/dokumenter/nou-20193/id2627718/

OECD (2016). PISA 2015 Results (Volume I). Excellence and Equity in Education. OECD Publishing.

Olsen, R.V. \& Björnsson, J.K. (2018). Tjue år med internasjonale skoleundersøkelser i Norge: Bakgrunn, læringspunkter og veien videre. I R.V. Olsen \& J.K. Björnsson (Red.), Tjue år med TIMSS og PISA i Norge. Trender og nye analyser. Universitetsforlaget. https://doi.org/10.18261/ 9788215030067-2018

Opplæringslova (1998). Lov om grunnskolen og den videregående opplæringa (LOV_1998_07_17_61). https://lovdata.no/dokument/NL/lov/1998-07-17-61/KAPITTEL_1\#\%C2\%A71-1

Osloskolen, Sommerskolen Oslo (2021). «Intensiv norskopplæring for nyankomne elever». https://sommerskolenoslo.no/norsk-for-nyankomne-elever/

Parszyk, I-M. (1999). En skola för andra. Minoritetselevers upplevelser av arbets- och livsvillkor i grundskolan. [Doktorgradsavhandling]. Stockholms Universitet, Sverige.

Puthenpura, S. \& Sinha, N.K. (1986). Modified maximum likelihood method for the robust estimation of system parameters from very noisy data. Automatica 22(2), 231-235. https://doi.org/10.1016/0005-1098(86)90085-3

Rutkowski, L., von Davier, M. \& Rutkowski, D. (2013). Handbook of international large-scale assessment: Background, technical issues, and methods of data analysis. CRC Press.

Saltnes, K.M. (2016). Flerspråklighet - teoretiske og ideologiske perspektiver - En studie av debatten om flerspråklighet og morsmålsundervisning. [Masteroppgave]. NTNU.

Sirin, S.R. (2005). Socioeconomic Status and Academic Achievement: A Meta-Analytic Review of Research. Review of Educational Research, 75(3), 417-453. https://doi.org/10.3102/ 00346543075003417

Sjøberg, S. (2009). Naturfag som allmenndannelse: en kritisk fagdidaktikk. Gyldendal akademisk.

Skaftun, A., Solheim, O.J. \& Uppstad, P.H. (2014). Leseboka - leseopploering i alle fag på ungdomstrinnet. Cappelen Damm AS.

Strietholt, R. (2014). Studying Educational Inequality: Reintroducing Normative Notions. I R. Strietholt, W. Bos, J.E. Gustafsson \& M. Rosén (Red.), Educational Policy Evaluation. Waxman. SSB (2021). Statistikkbanken. https://www.ssb.no/statbank/table/10516/tableViewLayout1/ 
Støle, H. \& Schwippert, K. (2017). Norske resultater fra e-PIRLS - online informational reading. I Gabrielsen, E. (Red.) Klar framgang! Leseferdighet på 4. og 5. trinn i et femtenårsperspektiv (s. 50-74). Universitetsforlaget.

Sæverud, O., Forseth, B.U., Ottem, E. \& Platou, F. (2011). Begrepslæring- en strukturert undervisningsmodell for barn og unge med språkvansker. Bredtvet kompetansesenter.

Van Laere, E., Aesaert, K. \& van Braak, J. (2014). The Role of Students' Home Language in Science Achievement: A multilevel approach. International Journal of Science Education 36(16). https://doi.org/10.1080/09500693.2014.936327

von Davier, M. (2014). Imputing Proficiency data under Planned Missingness in Population Models. I L. Rutkowski, M., von Davier \& D. Rutkowski (Red.), Handbook of International Largescale Assessment: background, technical issues, and methods of data analysis. In Statistics in the social and behavioral sciences series. Chapman \& Hall/CRC Press.

Wellington, J. \& Osborne, J. (2001). Language and Literacy in Science Education. Open University Press.

White, K.R. (1982). The relation between socio-economic status and academic achievement. Psychological Bulletin, 91(3), 461-481.

Ødegaard, M., Haug, B.S., Mork, S.M. \& Sørvik, G.O. (2016). På forskerføtter i naturfag. Universitetsforlaget. 